\title{
Design, Simulation and Analysis of Single Phase AC to DC Cuk Converter Fed Led Applications
}

\author{
R. Kalai Priya
}

Department of Electrical and Electronics Engineering, SRNM polytechnic College, Sattur, Tamilnadu, India

\author{
Article Info \\ Volume 7, Issue 4 \\ Page Number : 49-56 \\ Publication Issue : \\ July-August-2020
}

\section{Article History}

Accepted : 10 July 2020

Published : 20 July 2020

\begin{abstract}
This paper analysis with PFC Cuk converter fed LED drive to overcome the power factor problems. The proposed circuit topology consists of diode bridge rectifier and Cuk converter. Cuk converter is operated to work under CCM mode. This combination of DBR and PFC converter is used to feed a LED drive. This converter is simulated in MATLAB software. This Cuk converter provides better results such as unity power factor and low current harmonic distortion with fuzzy logic control and hysteresis control.
\end{abstract}

Keywords : Power factor, THD, Cuk converter, CCM, Fuzzy logic control

\section{INTRODUCTION}

Conventional light emitting diode (LED) drivers with diode bridge rectifier suffer the problem of low circuit efficiency, low power factor and low reliability. LED driver circuit connected to alternating current (AC) line source generally needs an additional power factor correction (PFC) stage to overcome the problem on power factor (PF) and total harmonic distortion (THD). It leads to more circuit loss in PFC stage.

In conventional converter like three phase ac-dc boost are used to increase the power factor system [1$3]$. But, three phase boost converter only suitable for high power applications. Single phase AC-DC boost converters are used for LED drivers [4-5]. These converters require bulky inductance. Cuk converters are used to improve the power quality of LED driver [6-8]. Cuk converter provides negative output voltage and require current and voltage sensor. Modified Sepic converters are used as power factor correction
[9-13]. These converters also require two sensing units and only provide boost operation. Three level AC-DC converters also employed as LED drivers in marine applications [14-18]. But these converters require two switches and complex control circuit. Luo converters are developed to improve the power quality the LED lighting system [19-23]. These converters are non isolated converter and it provides negative output voltage. Single phase Zeta converter is used as LED Street lighting [24-26]. This paper deals with AC-DC Cuk converter for LED lighting system for improvement of power quality. So we are in the need of converter to overcome these issues to drive the LED for better performance. Hence the objective of the problem is to improve the power factor and to minimize total harmonic distortion and maximize the efficiency with the help of Fuzzy controller to generate the PWM to turn on/off the switches used in the converter. It is a simulation and model based design environment integrated with MATLAB. 
Recently Cuk converter attains major role in DC/DC converter topology. It is a fourth order $\mathrm{DC} / \mathrm{DC}$ converter made up of two inductor and two capacitors. It is capable of increase and decreases the input voltage levels with inverting the polarities. Cuk converter, which is originally, comes the buck boost type.

\section{Operation of Cuk converter}

The proposed PFC Cuk converter is fed to LED. A single phase AC supply is feed to the diode bridge rectifier the followed by LC filter and an isolated Zeta converter. The purpose of the filter is to avoid the ripples in the input side due to switching. The proposed isolated converter is designed to operate in continuous mode. Output voltage is controlled with the help of PI controller. The repeating sequence and PI controller is used to generate PWM pulses for the MOSFET switches. A simple block diagram represents the proposed design as shown in the Fig. 1.

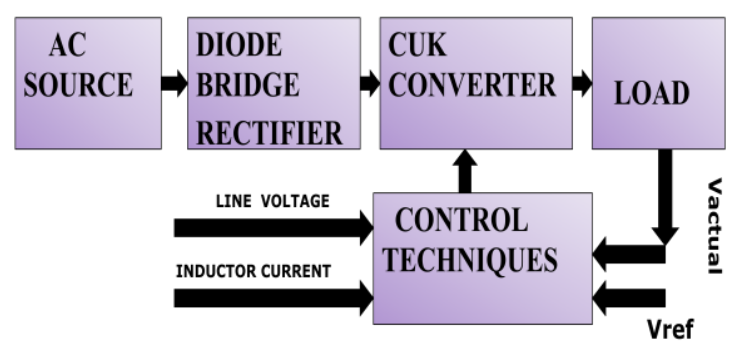

Fig. 1: Block diagram MODES OF OPERATION

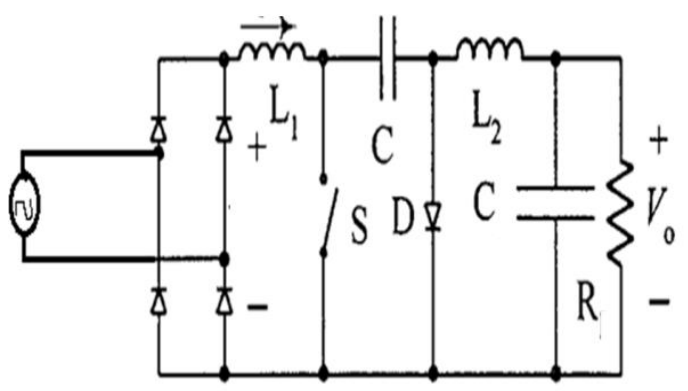

Fig. 2: Circuit diagram

The Cuk converter is a step-down/step-up converter based on a switching boost-buck topology. It is shown in figure 2. Cuk converter provides an output voltage less than or greater than the supply voltage but the output voltage polarity is opposite to that of supply voltage. Capacitor is used for energy transfer in this converter whereas other converters uses inductor for energy transfer .Main purpose of capacitor $\mathrm{C} 1$ is to transfer energy from source to load.

\section{MODE 1: SWITCH ON MODE}

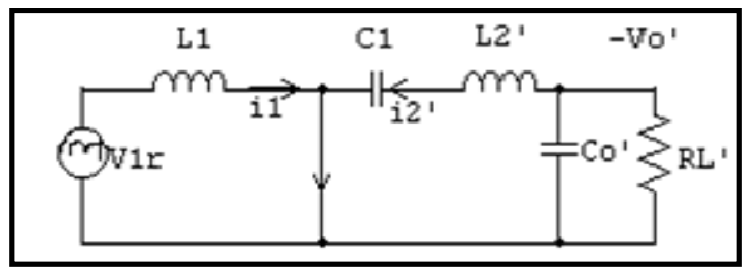

Fig. 3 : Mode 1

When switch is ON(Fig. 3), the two inductor currents rises linearly with the voltage across them equal to the input voltage .The equations for the inductor currents during the interval $0<\mathrm{t}<\mathrm{dTs}$ are given by the equations ,

$$
\begin{array}{r}
\mathrm{i}_{1}=\mathrm{i}+\frac{V_{l r}}{L_{1}} \mathrm{t} \\
\mathrm{i}_{2}=-\mathrm{i}+\frac{\mathrm{V}_{l \mathrm{r}}}{\mathrm{L}_{2}{ }^{\prime}} \mathrm{t}
\end{array}
$$

\section{MODE 2: SWITCH OFF MODE}

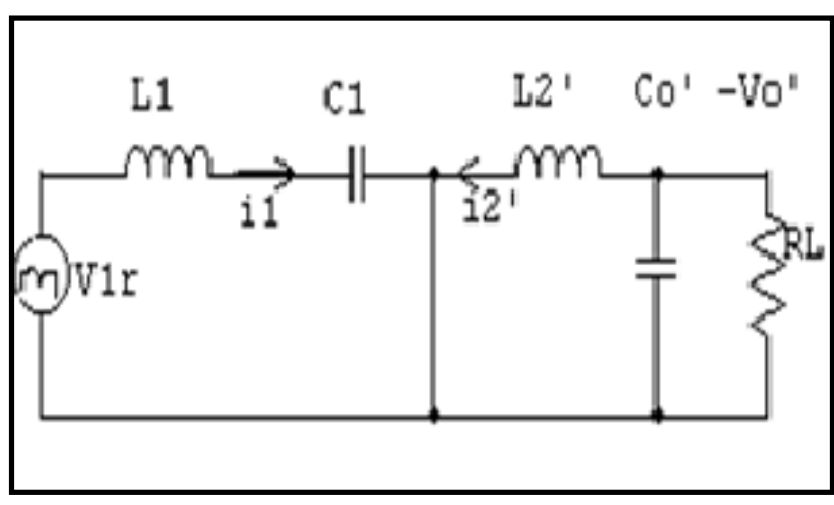

Fig. 4 Mode 2

When the switch is OFF (Fig. 4), inductor currents decrease linearly with the voltage equal to the output voltage. The inductor current equations are given by,

$$
\mathrm{i}_{1}=-\frac{V_{o}^{\prime}}{L_{1}} t+\frac{V_{l r}}{L_{1}} d T_{s}+i
$$




$$
\mathrm{i}_{2}{ }^{\prime}=-\frac{V_{o}{ }^{\prime}}{L_{2}{ }^{\prime}} t+\frac{V_{l r}}{L_{2}{ }^{\prime}} d T_{s}-i
$$

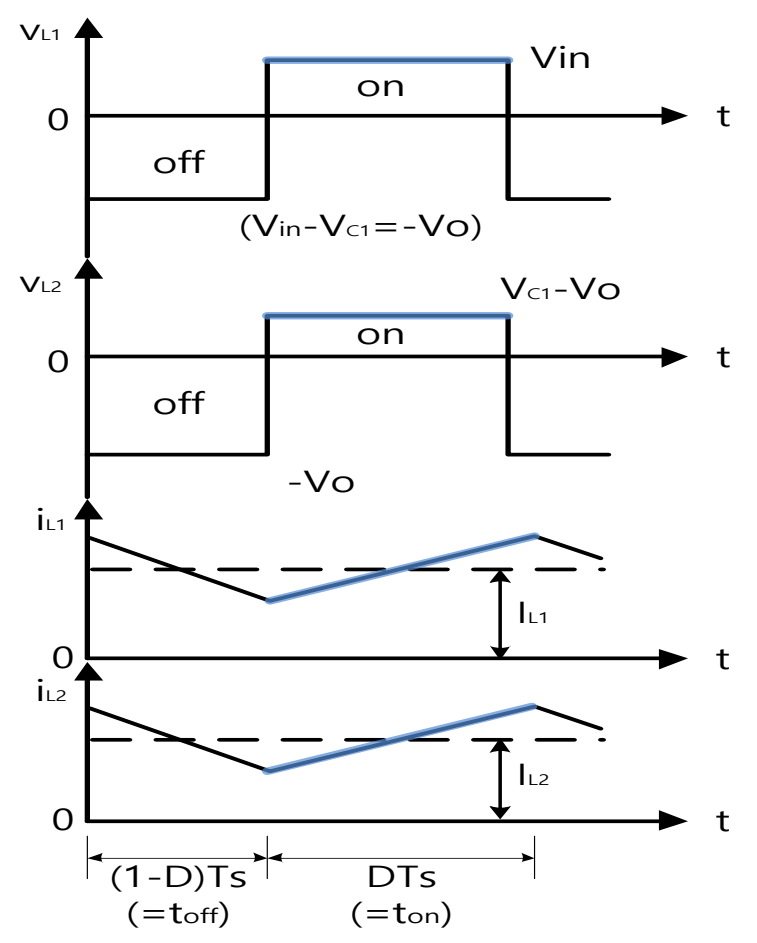

Fig. 5 : Switching waveforms

Figure 5 shows the switching waveforms of Cuk converter.

\section{ADVATAGES OF CUK CONVERTER}

- Output voltage may be greater than or less than the peak input voltage.

- Easy implementation of high frequency insulation; provides better control

- No need for additional commutation circuit

- Efficiency gets improved

- Low weight and fast operation.

\section{DESIGN OF PFC BASED CUK CONVERTER}

The Zeta converter is operated in discontinuous mode of operation. It involves the design of various elements such as magnetizing inductor, intermediate capacitor, dc link capacitor. This will be discussed in below:

Outputvoltage

$$
\begin{array}{ll} 
& \mathrm{V}_{\mathbf{o}}=\frac{\mathrm{K} \mathrm{V}}{1-\mathrm{K}} \\
\text { Inductance }= & \mathrm{L} 1=\mathrm{L} 2=\frac{\mathrm{K} \mathrm{V}}{\mathrm{f} \Delta \mathrm{I}_{2}} \\
\text { Capacitance }= & \mathrm{C} 1=\frac{\mathrm{I}_{\mathrm{S}}(1-\mathrm{K})}{\mathrm{f} \Delta \mathrm{V}_{\mathrm{c} 1}} \\
\mathrm{C} 2=\frac{\Delta \mathrm{I}_{2}}{6 \mathrm{f} \Delta \mathrm{V}_{\mathrm{c} 2}}
\end{array}
$$

Table 1 Design parameters

\begin{tabular}{|c|c|}
\hline $\begin{array}{c}\text { DESIGN } \\
\text { PARAMETER }\end{array}$ & VALUES \\
\hline $\begin{array}{c}\text { Input line } \\
\text { voltage }\end{array}$ & $20 \mathrm{~V}$ \\
\hline Output voltage & $48 \mathrm{~V}$ \\
\hline $\begin{array}{c}\text { Switching } \\
\text { frequency }\end{array}$ & $10 \mathrm{kHz}$ \\
\hline Line frequency & $50 \mathrm{~Hz}$ \\
\hline Inductance (L1=L2 & $2.6 \mathrm{mH}$ \\
\hline Capacitance $\mathrm{C}_{1}$ & $0.001455 \mu \mathrm{F}$ \\
\hline Capacitance $\mathrm{C}_{2}$ & $0.0125 \mu \mathrm{F}$ \\
\hline Load resistance & $50 \Omega$ \\
\hline
\end{tabular}

The values for the inductor, dc link capacitor, output inductor, intermediate capacitors, inductance and capacitance of inductor and capacitor are calculated by keeping ripple values of output current and output voltage. The switching frequency is chosen as $10 \mathrm{kHz}$. The specification used in the design model is tabulated as shown in the table 1 


\section{OPEN LOOP CONFIGURATION}

It consists of source voltage which is fed to the diode bridge rectifier. The output of the diode bridge rectifier is fed into the Cuk converter with the resistive load. Switching frequency for the MOSFET switch would be $10 \mathrm{kHz}$. It is shown in figure 6 .

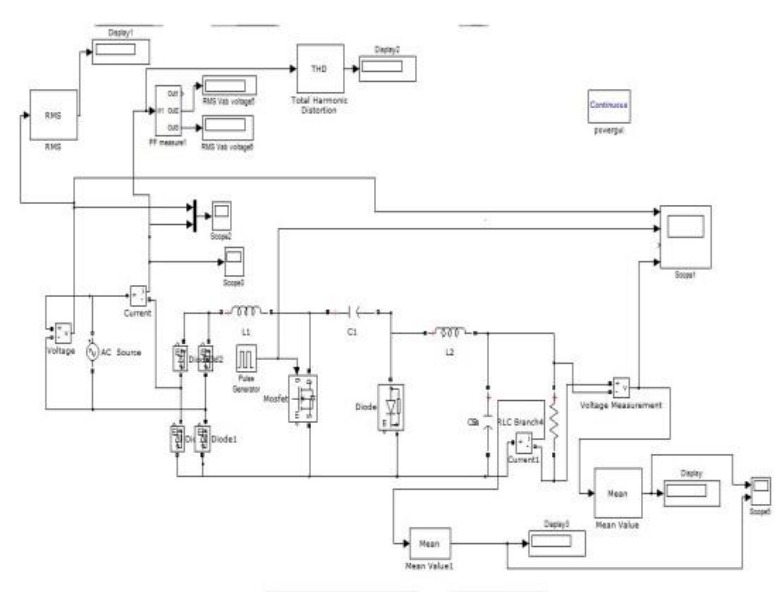

Fig. 6 Open loop Simulation

\section{CLOSED LOOP CONFIGURATION}

The open loop configuration of the converter is changed to closed loop controlled converter with Fuzzy control and hysteresis control. The comparator, repeating sequence, Fuzzy controller is used to generate the PWM pulse for MOSFET switches to regulate output voltage constant for varying supply voltage and for varying load. Closed loop configuration is shown in Fig.7.

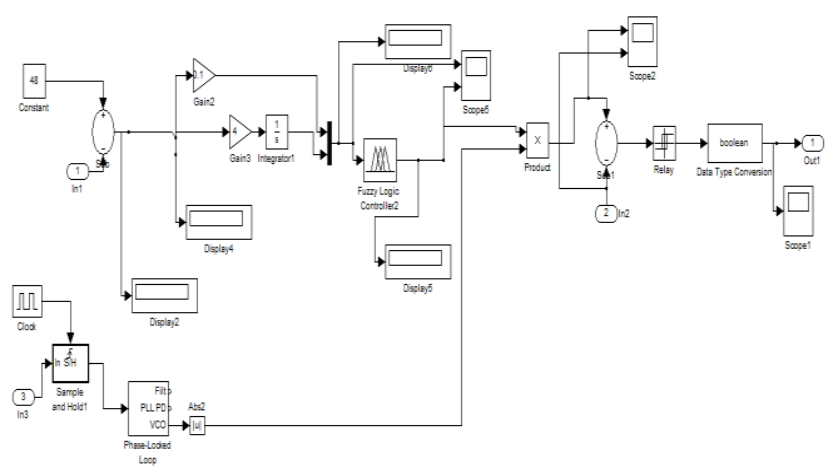

Fig. 7 Closed loop Simulation
Fuzzy logic is a mathematical logic that attempts to solve problems by assigning values to an imprecise spectrum of data in order to arrive the most accurate conclusion. It is designed to solve problems in the same way that humans do by considering all available information and making the best possible decision. Table 2 shows the membership degree of mapping between input and output functions based on fuzzy if then rules. This table is called fuzzy associative memory table.

Table 2 : Fuzzy rules

\begin{tabular}{|l|l|l|l|l|l|}
\hline $\begin{array}{l}\text { CER } \\
\text { ER }\end{array}$ & NB & NS & ZE & PS & PB \\
\hline NB & NB & NB & NS & ZE & PS \\
\hline NS & NB & NS & NS & E & PS \\
\hline ZE & NS & NS & ZE & PS & PB \\
\hline PS & PS & ZE & PS & PS & PB \\
\hline PB & PB & PS & PS & PB & PB \\
\hline
\end{tabular}

\section{ANALYSIS OF VARYING INPUT VOLTAGE}

By keeping the load constant, the input voltage is varied widely to understand the performance of the converter for varying input voltage, power factor, output voltage, total harmonic distortion readings are noted and tabulated as in table 3

Table 3 : Analysis of Input voltage

\begin{tabular}{|c|c|c|c|c|}
\hline S.no & Vin (V) & Vo (V) & PF & $\begin{array}{c}\text { Is } \\
\text { THD (\%) }\end{array}$ \\
\hline 1. & 15 & 48.0 & 0.997 & 3.8 \\
\hline 2. & 20 & 47.9 & 0.998 & 3.9 \\
\hline 3. & 25 & 48.0 & 0.996 & 4.5 \\
\hline
\end{tabular}




\section{ANALYSIS OF VARYING OUTPUT LOAD}

For determining the input current, THD, power factor, output current, output voltage for varying load, keep the input voltage at constant 20V. The resistive load is varied and readings are tabulated as in the table 4 .

Table 4 : Analysis of varying load

\begin{tabular}{|c|c|c|c|c|c|}
\hline S.no & $\begin{array}{c}\text { Vin } \\
(\mathrm{V})\end{array}$ & $\begin{array}{c}\text { Vo } \\
(\mathrm{V})\end{array}$ & $\begin{array}{c}\text { THD } \\
(\%)\end{array}$ & PF & $\mathrm{R}_{\mathbf{L}}$ \\
\hline 1. & 20 & 48.01 & 3.39 & 0.997 & 50 \\
\hline 2. & 20 & 48 & 4.83 & 0.993 & 100 \\
\hline
\end{tabular}

\section{VII.SIMULATION WAVEFORMS}

Simulation is performed in the MATLAB for the proposed converter design. Power factor is maintained almost unity.THD is maintained below 4\% which is the acceptable range of value. Parameter values used for the simulation work are found out from equation available.. Source voltage and source current is simulated and graph is obtained in the scope of SIMULINK which is shown in the Fig. 8. The input $20 \mathrm{~V}, 50 \mathrm{~Hz}$ is given to the circuit. The power factor is maintained almost unity.

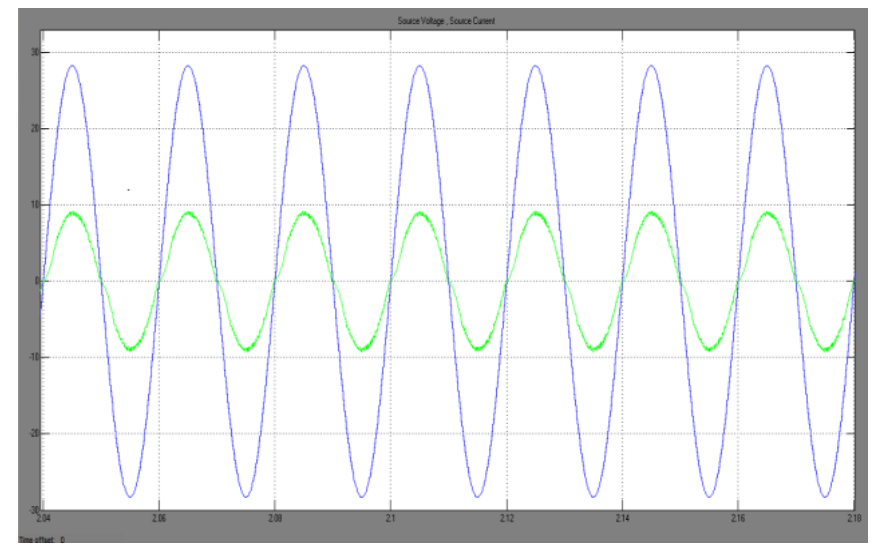

Fig. 8 Input voltage waveform
The source current THD is less than $4 \%$.

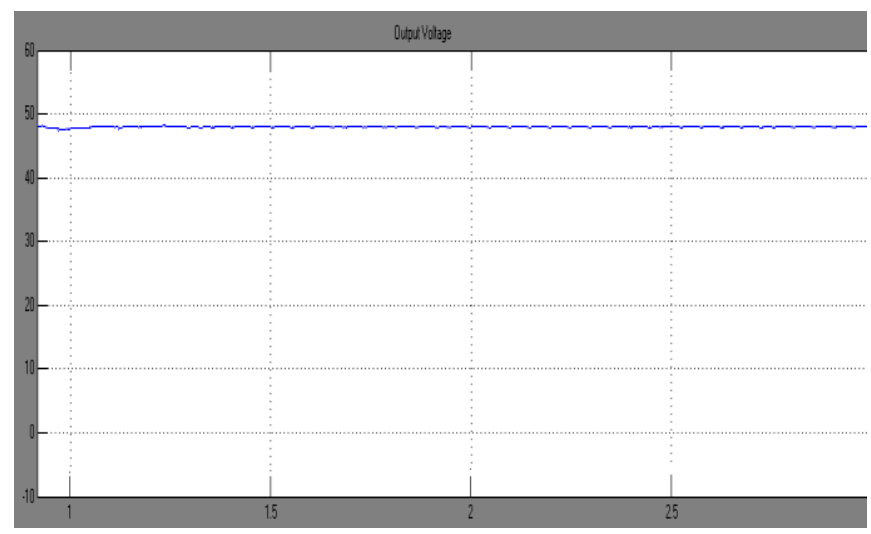

Fig. 9 Output voltage waveform

Output voltage also obtained in the scope of the MATLAB software as shown in the Fig. 9.

The output voltage is regulated at $48 \mathrm{~V}$.

\section{CONCLUSION}

The single phase AC-DC Cuk converter was simulated with variation in load. The voltage unbalance problem is improved by using proposed cuk converter. The simulation was done for single phase AC-DC cuk converter with the fuzzy voltage controller and hysteresis current controller. This controller provides unity power factor, voltage regulation, less harmonic distortion, high efficiency and good steady state performance .. The fuzzy voltage controller and hysteresis current controller gives very low THD of $3.90 \%$ and unity power factor. The THD lies within 5\% which an IEEE standard even for wide range of load variation. The proposed converter is suitable for LED drives to operate efficiently.

\section{REFERENCES}

[1]. B. Singh, B. N. Singh, A. Chandra, K. AlHaddad, A. Pandey and D. P. Kothari, "A review of single-phase improved power quality AC-DC converters," in IEEE Transactions on 
Industrial Electronics, vol. 50, no. 5, pp. 962981, Oct. 2003, doi: 10.1109/TIE.2003.817609.

[2]. J.Gnanavadivel, R.Thangasankaran, N.Senthil Kumar, K.S.Krishnaveni "Performance Analysis of PI Controller and PR Controller Based Three - Phase AC-DC Boost Converter with Space Vector PWM" International Journal of Pure and Applied Mathematics, vol-118,issue(24),pp 116,2018

[3]. Gnanavadivel, J., Devapriya, R., Senthil Kumar, N., Jaya Christa, S.T. "Performance investigation of fuzzy controller, PI controller and hysteresis current controller based three - Phase AC-DC boost converter" International Journal of Applied Engineering Research, vol10,issue(66),pp 276-283,2015

[4]. E. Divya and J. Gnanavadivel, "Harmonic elimination in three phase PWM rectifier using FPGA control," 2011 International Conference on Emerging Trends in Electrical and Computer Technology, Nagercoil, 2011, pp. 436-441, doi: 10.1109/ICETECT.2011.5760156.

[5]. P. Shobana, N. Geetha and J. Gnanavadivel, "Enhancement of power quality of AC-DC Boost converter with HCC and FLC-A comparative study," 2012 International Conference on Computing, Electronics and Electrical Technologies (ICCEET), Kumaracoil, 2012, pp. 254-258, doi: 10.1109/ICCEET.2012.6203829.

[6]. M. B. Lakshmi, R. Thangasankaran, J. Gnanavadivel and S. T. J. Christa, "Performance Evaluation of Fuzzy Controlled Single Phase PWM Rectifier," 2018 Second International Conference on Electronics, Communication and Aerospace Technology (ICECA), Coimbatore, 2018, pp. 1974-1979, doi: 10.1109/ICECA.2018.8474707.

[7]. J. Gnanavadivel, V. Chellappa and N. Senthil Kumar, "Comparison of Power Quality Improvement techniques in AC-DC Cuk
Converter," 2011 International Conference on Computer, Communication and Electrical Technology (ICCCET), Tamilnadu, 2011, pp. 400-404, doi: 10.1109/ICCCET.2011.5762508.

[8]. V. Chellappa, J. Gnanavadivel and N. S. Kumar, "Power quality improvement techniques in ACDC Cuk Converter," 2011 International Conference on Emerging Trends in Electrical and Computer Technology, Nagercoil, 2011, pp. 430-435, doi: 10.1109/ICETECT.2011.5760155.

[9]. J Gnanavadivel, $\mathrm{P}$ Yogalakshmi, N Senthil Kumar, S Muralidharan "High efficient single stage Cuk LED driver for universal input voltage applications with improved power quality" Optoelectronics and Advanced Materials-Rapid Communications, vol12,issue(11-12),pp 694-699,2018

[10]. E. T. R. Smiline, J. Gnanavadivel, S. T. J. Christa and N. S. Kumar, "Performance evaluation of PI and fuzzy tuned PI controllers for single phase bridgeless modified SEPIC converter," 2016 International Conference on Circuit, Power and Computing Technologies (ICCPCT), Nagercoil, 2016, pp. 1-6, doi: 10.1109/ICCPCT.2016.7530120.

[11]. B. Karthikeyan, S. T. J. Christa and J. Gnanavadivel, "Modeling and Evaluation of Modified SEPIC Converter Fed BLDC Motor Drive," 2018 Second International Conference on Electronics, Communication and Aerospace Technology (ICECA), Coimbatore, 2018, pp. 1900-1905, doi: 10.1109/ICECA.2018.8474887.

[12]. J Gnanavadivel, NS Kumar, STJ Christa, P Yogalakshmi "Design and Implementation of High Power LED Lighting System for Health Care Applications" Current Signal Transduction Therapy, vol-14,issue(1),pp 31-37,2019

[13]. N Rathina Prabha, J Gnanavadivel, KS .Krishna Veni "Performance Investigation of Single Switch Dual Output DC-DC SEPIC Converter for PV Applications" International Journal of 
Advanced Science and Technology, vol29,issue(5),pp 4676-4683,2020

[14]. J Gnanavadivel, N Senthil Kumar, ST Christa, S Muralidharan "Design and implementation of FPGA-based high power LED lighting system for ships" Indian Journal of Geo Marine Sciences, vol-48,issue(5),pp 724-729,201

[15]. J Gnanavadivel, N Senthil Kumar, ST Christa, S Muralidharan "Design and implementation of FPGA-based high power LED lighting system for ships" Indian Journal of Geo Marine Sciences, vol-48,issue(5),pp 724-729,201

[16]. J Gnanavadivel, N Senthil Kumar, P Yogalakshmi "Implementation of FPGA based three-level converter for LIED drive applications" Journal of Optoelectronics And Advanced Materials , vol-18,issue(5-6),pp 459467,2016

[17]. J.Gnanavadivel, $\mathrm{N}$ Senthil Kumar, $\mathrm{P}$ Yogalakshmi "Comparative Study of PI, Fuzzy and Fuzzy tuned PI Controllers for Single-Phase AC-DC Three-Level Converter" Journal of Electrical Engineering \& Technology, vol12,issue(1),pp 78-90,2017

[18]. J Gnanavadivel, N Senthil Kumar, P Yogalakshmi "Implementation of FPGA based fuzzy and hysteresis controllers for power quality improvement in single phase three-level rectifier" Optoelectronics and Advanced Materials-Rapid Communications, vol-9, issue(910),pp 1264-1272,2015

[19]. J Gnanavadivel, $\mathrm{N}$ Senthil Kumar, $\mathrm{P}$ Yogalakshmi "Fuzzy controller based power quality improvement in three level converter with multiloop interleaved control for marine AC/DC applications" Indian Journal of Geo Marine Sciences, vol-46,issue(9),pp 19081919,2017

[20]. J. Gnanavadivel, N. Senthil Kumar, C. N. Naga Priya, S. T. Jaya Christa, K. S. Krishna Veni "Single phase positive output super-lift luo converter fed high power LED lamp with unity power factor and reduced source current harmonics" Journal of Optoelectronics And Advanced Materials , vol-18,issue(Nov-Dec 2016),pp 1007-1017,2016

[21]. R. Thanzasankaran, S. T. J. Christa, J. Gnanavadivel and N. Kumar, "Design and Analysis of Negative Output Luo Converter for Power Quality Enhancement," 2018 International Conference on Current Trends towards Converging Technologies (ICCTCT), Coimbatore, 2018, pp. 1-6, doi: 10.1109/ICCTCT.2018.8550969.

[22]. J. Gnanavadivel, P. Yogalakshmi, N. Senthil Kumar and K. S. Krishna Veni, "Design and development of single phase AC-DC discontinuous conduction mode modified bridgeless positive output Luo converter for power quality improvement," in IET Power Electronics, vol. 12, no. 11, pp. 2722-2730, 189 2019, doi: 10.1049/iet-pel.2018.6059.

[23]. J Gnanavadivel, N Senthil Kumai, CN Naga Priya, KS Krishna Veni "Investigation of Power Quality Improvement in Super Lift Luo Converter" International Journal of Power Electronics and Drive Systems, vol-8,issue(3),pp 1240-1250,2017

[24]. S. Muthukaruppasamy , A. Abudhahir, A. Gnana Saravanan, J. Gnanavadivel, Duraipandy "Design and Implementation of PIC/FLC plus SMC for Positive Output Elementary Super Lift Luo Converter working in Discontinuous Conduction Mode" Journal of Electrical Engineering \& Technology, vol-13,issue(5),pp 1886-1900,2018

[25]. Bhim Singh, MahimaAgrawal, SanjeetDwivedi, "Analysis, Design, and Implementation of a Single-Phase Power-Factor Corrected AC-DC Zeta converter with High Frequency Isolation", Journal of Electrical Engineering \& Technology , vol-3,issue(2),pp 243-253,2008. 
[26]. N. Ramaprabha, J. Gnanavadivel, N. S. Kumar and S. T. J. Christa, "Power quality improvement in single phase AC to DC zeta converter," IET Chennai Fourth International Conference on Sustainable Energy and Intelligent Systems (SEISCON 2013), Chennai, 2013, pp. 533-537, doi: 10.1049/ic.2013.0366.

[27]. J. Siva Alagesan, J. Gnanavadivel, N. Senthil Kumar and K. S. Krishna Veni, "Design and Simulation of Fuzzy based DC-DC Interleaved Zeta Converter for Photovoltaic Applications," 2018 2nd International Conference on Trends in Electronics and Informatics (ICOEI), Tirunelveli, 2018, pp. 704-709, doi: 10.1109/ICOEI.2018.8553836.

\section{Cite this article as :}

Sh

R. Kalai Priya , "Design, Simulation and Analysis of Single Phase AC to DC Cuk Converter Fed Led Applications", International Journal of Scientific Research in Science and Technology (IJSRST), Online ISSN : 2395-602X, Print ISSN : 2395-6011, Volume 7 Issue 4, pp. 49-56, July-August 2020. Available at doi : https://doi.org/10.32628/IJSRST207420

Journal URL : http://ijsrst.com/IJSRST207420 